\title{
EVALUATION CRITERIA OF ELECTRONIC EDUCATION MATERIALS DISPLAYED BY WEB BROWSERS
}

\section{Petr PEXA}

\begin{abstract}
The article describes the results of research conducted within the dissertation thesis elaborated by the author among teachers at elementary and secondary schools in the South Bohemian region. Research informants classified selected criteria for evaluation of educational webpages via Qmetodology statistical method and tested their priority for creation and evaluation of teaching materials usable in real pedagogical process and displayed by web browsers.
\end{abstract}

Key words: Computer technology, Information and communication technology, School information system, Educational websites, Evaluation of educational websites, Criteria for evaluation of educational websites.

\section{KRITÉRIA HODNOCENÍ ELEKTRONICKÝCH VZDĚLÁVACÍCH MATERIÁLŮ ZOBRAZOVANÝCH WEBOVÝMI PROHLÍŽEČI}

Resumé: Článek popisuje výsledky výzkumného šetření, které bylo provedeno v rámci zpracování disertační práce autorem mezi vyučujícími na základních a středních školách v Jihočeském regionu. Respondenti výzkumu tř́́dili předložená kritéria evaluace výukových www stránek pomocí statistické metody Q-metodologie a testovali tak jejich prioritu pro tvorbu a hodnocení výukových materiálů využitelných v reálném pedagogickém procesu a zobrazovaných webovými prohlížeči.

Klićcová slova: Výpočetní technika, Informační a komunikační technologie, Informační systém školy, Výukové webové stránky, Evaluace výukových webových stránek, Kritéria evaluace výukových webových stránek.

\section{1 Úvod}

$\mathrm{V}$ rámci zpracování disertační práce byl autorem připraven výzkum mezi učiteli na základních a středních školách v Jihočeském regionu. Byly sestaveny konkrétní Q-typy formou otázek, testující prioritu předem navržených kritérií evaluace a dotazník zjišt'ující základní statistická data respondentů (věk, délka praxe, pohlaví, odborné zaměření, typ a sídlo školy, používání ICT, internetu a výukových webových stránek ve výuce apod.). Třetím a nejdůležitějším dokumentem, který byl ve výzkumu na školách použit, byl formulář pro vyhodnocení všech stanovených kritérí.

\section{Cíle výzkumného šetření}

Hlavním cílem disertační práce bylo navrhnout a vlastním výzkumem na konkrétním vzorku vyučujících na základních a středních školách ověrit sadu kritérií pro hodnocení výukových webových stránek a e-learningových výukových systémů pro základní a střední školy.

Dílčí skupinu cílů tvořili cíle empirické a aplikační. Na základě výzkumného šetření byla zjištována aktuální situace využívání výukových www stránek vyučujícími na základních a středních školách v Jižních Čechách a především názor učitelů na důležitost jednotlivých kritérií hodnocení výukových www stránek. Ke splnění těchto cílů byla využita moderní statistická metoda Q-metodologie, na jejímž základě bylo možné následně stanovit prioritu a význam jednotlivých evaluačních kritérií a tím poskytnout vyučujícím i tvưrcům výukových www stránek vhodný a použitelný evaluační nástroj.

\section{Popis výzkumného vzorku}

Se žádostí o participaci na výzkumu bylo osloveno 12 škol v Jihočeském regionu, na realizaci se nakonec podílela většina vyučující čtyř škol (ZŠ Máj a ZŠ O. Nedbala v Českých Budějovicích, ZŠ Soběslav a Gymnázium Pražská v Č. Budějovicích) a několik jednotlivců ze škol ostatních. Do škol bylo osobně autorem distribuováno 125 dotazníkủ, vráceno bylo 82 , $\mathrm{z}$ toho 55 žen a 27 mužů. 32 respondentů bylo mladších 40ti let a 17 vyučovalo informatiku a podílelo se zároveň na tvorbě či správě webových stránek školy.

Určitou překážkou se ukázala předem zvolená statistická metoda Q-metodologie. Ta je sice 
velmi vhodná pro intenzívní zkoumání menšího počtu osob a nejvíce zároveň vyhovovala výzkumným záměrům autora s hodnocením kritérií ve formě tzv. Q-typů, ale je pro respondenty značně časově i částečně odborně náročná. $Z$ tohoto důvodu byl vedením většiny oslovených škol podíl na výzkumu odmítnut.

Výzkum byl tedy proveden vzhledem $\mathrm{k}$ použité metodě sběru dat (Q-metodologie) na užším vzorku 82 učitelů různého věku, pohlaví, délky pedagogické praxe, s různým odborným zaměřením (humanitní, prírodovědné, informatika) i působností (město/venkov, základní resp. střední škola), viz kapitola Výstupy pedagogického výzkumu.

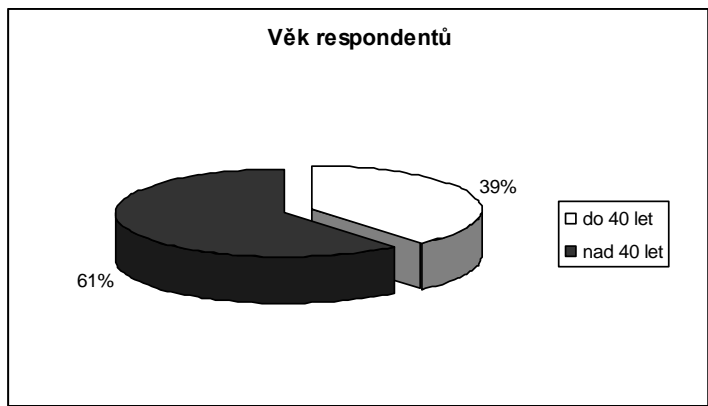

Obr. 1: Struktura respondentů v závislosti na věku

Hodnocení Q-typů prováděli respondenti po společném seznámení a instruktáži ze strany autora samostatně $\mathrm{z}$ důvodů nutnosti podrobnějšího prostudování problematiky.

Data získaná výzkumem byla zpracována tabulkovým kalkulátorem Microsoft Excel a statisticky vyhodnocena $\mathrm{z}$ mnoha pohledů programem Statistica.

\section{Zpracování výzkumu}

$\mathrm{K}$ vlastnímu sběru dat $\mathrm{v}$ prodeném výzkum byla použita metoda Q-metodologie. Tímto statistickým termínem se označuje skupina psychomotorických a statistických procedur, který vyvinul v 50. letech 20 . století William Stephenson. Metoda je výhodná ve výzkumech, v nichž máme zjistit, jak určitá skupina respondentů hodností určitou množinu objektů, prričemž těchto objektů je velký počet (Chráska, 2007).

Z druhého pohledu je tato metoda vhodná k intenzivnímu zkoumání menších skupin osob. U Q-metodologie se zkoumaným osobám předkládá soubor (balíček) karet, na nichž jsou uvedeny objekty, které se mají hodnotit tak, že je respondenti mají roztř́dit podle různých kritérií - napřr. podle důležitosti pro zkoumanou osobu. Jako optimální počet karet se doporučuje 60-120.

Po zkoumané osobě se požaduje, aby karty rozdělila do několika hromádek podle stanoveného kritéria, nejčastěji se požaduje tzv. kvazinormální rozdělení, které přibližně odpovídá normálnímu rozdělení podle Gaussovy křivky (hustota normálního rozdělení pravděpodobnosti). Kvazinormální distribuce má tu výhodu, že umožňuje a usnadňuje statistické zpracování výsledků. F. N. Kerlinger (1972) hovoří $v$ této souvislosti o používání Q-metodologie k „,heuristickým účelům“.

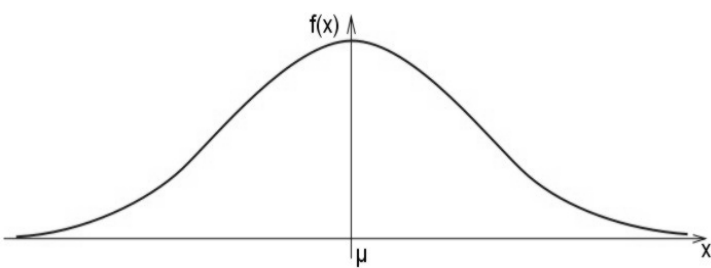

Obr. 2: Gaussova křivka - hustota normálního rozdělení pravděpodobnosti

Gaussova křivka je souměrná podle osy, procházející jejím vrcholem, vrchol křivky odpovídá aritmetickému průměru všech naměřených hodnot. Křivka nikde neprotíná vodorovnou osu, ale stále se $\mathrm{k}$ ní blíží, tvar křivky je závislý na velikosti standardní odchylky (s větší odchylkou je křivka plošší a naopak).

Pravděpodobnost výskytu určité hodnoty x lze u normálního rozdělení vypočítat ze vztahu:

$$
f(x)=\frac{1}{\sigma \sqrt{2 \pi}} \mathrm{e}^{-\frac{(x-\mu)^{2}}{2 \sigma^{2}}}
$$

kde $f(x)$ je tzv. hustota pravděpodobnosti, $\sigma$ směrodatná odchylka základního souboru, $\pi$ je Ludolfovo číslo $(3,14159)$, e základ přirozených logaritmů $(2,71282), \quad \mu$ aritmetický průměr základního souboru a $\mathrm{x}$ je hodnota, jejíž pravděpodobnost výskytu se vypočítává (Chráska, 2007).

82 respondentů vlastního výzkumu vyhodnotilo předložené karty s navrženými Q-typy pomocí předloženého formuláře. Získaná data byla zpracována do základního souboru tabulkovým kalkulátorem MS Excel a dále byla importována do programu Statistica. Nejprve bylo provedeno měření reliability (spolehlivosti měření). Stupeň reliability se vyjadřuje koeficientem reliability, což je číslo nabývající hodnot od 0 do +1 , přičemž platí, že maximální hodnota +1 vyjadřuje ideální stupeň reliability. 
K tomuto účelu byl ve vlastním výzkumu použit výpočet Cronbachova koeficientu alfa. Tato metoda vychází z tzv. dvojnásobné analýzy rozptylu a je v programu Statistica dostupná jako jedna z možností stanovení reliability měření.

Základem vlastního výzkumu bylo zjistit, jak jednotlivé skupiny respondentů (učitelů) hodnotí předložená kritéria, tedy zda je rozdíl v hodnocení Q-typů (kritérií) mezi mladšími a staršími učiteli, mezi muži a ženami, mezi učiteli na základních a středních školách, mezi učiteli humanitních předmětů a předmětů prírodovědných, atd., těchto porovnání bylo provedeno celkem 10.

K tomuto účelu byla použita statistická metoda pro testování hypotéz Studentův t-test, který je jedním z nejznámějších parametrických statistických testů významnosti. Pomocí tohoto testu můžeme rozhodnout, zda dva soubory dat získané měřením ve dvou různých skupinách objektů mají stejný aritmetický průměr. U Studentova t-testu se požaduje, aby základní soubor dat splňoval požadavek normálního rozdělení (to je splněno použitím metody Q-metodologie).

Další použitou statistickou metodou ve výzkumu byl Spearmanův koeficient pořadové korelace. Ten zjišt'uje stupeň závislosti mezi dvěma sledovanými jevy, které jsou zachyceny pomocí ordinálního (pořadového) měření. Tento koeficient korelace umožňuje kvantitativně stanovit, jak těsná je souvislost mezi jevy, na základě nichž byla tato pořadí vytvořena, resp. jak dalece jsou si dvě vytvořená pořadí podobná. Koeficient může nabývat hodnot od 0 do \pm 1 . Hodnota 0 vypovídá o tom, že mezi srovnávanými jevy není žádný vztah a čím více se vypočítaná hodnota blíží hodnotě 1 (nebo -1), tím těsnější je vztah mezi porovnávanými jevy.

Názory učitelů na význam jednotlivých kritérií evaluace výuových webových stránek jsme tedy zjišt'ovali pomocí Q-metodologie. Pracovali jsme se sadou otázek, které byly učitelům předloženy na souboru 60 očíslovaných Q-typů formou karet, které reprezentovaly možné odpovědi na námi formulovanou základní otázku: „Jak velkou důležitost mají kritéria uvedená na kartách pro dobrý průběh vyučování pomocí výukové webové stránky?“"

Q-typy byly vytvořeny na základě studia odborné literatury v rámci vypracování jednotlivých kapitol teoretické části práce tak, aby vystihovaly naše výzkumné záměry. Nepodstatnou roli při formulování jednotlivých Q-typů sehrály i dlouholeté zkušenosti autora práce $\mathrm{s}$ tvorbou a výukou tvorby webových stránek na Pedagogické fakultě Jihočeské univerzity v Českých Budějovicích.

\section{Vybrané výstupy pedagogického výzkumu}

- Výpočet reliability (Cronbachovo alfa): 0,955409. Reliabilita měření je tedy velmi vysoká a získaná data lze považovat za poměrně spolehlivá.

- Vliv věku učitelů na pořadí důležitosti předložených kritérií pro hodnocení výukových webových stránek.

Cúlem této části výzkumu bylo prokázání nezávislosti věku učitelů na pořadí důležitosti kritérí́ evaluace výukových www stránek na základě použití statistické metody t-test. Pro tento test byl vzorek respondentů rozdělen podle věku na dvě skupiny: mladší učitelé (věk do 40 let), starší učitelé (věk nad 40 let). Nejprve bylo programem Statistica stanoveno pořadí hodnocení kritérií evaluace výukových www stránek.

Níže uvedená hypotéza byla ověřena na vzorku 82 respondentů pomocí t-testu pro nezávislé skupiny, kdy tzv. grupovací proměnnou byl věk respondentů (mladší učitelé do 40 let, starší učitelé nad 40 let).

Hypotéza: starší i mladší učitelé pokládají jednotlivé oblasti hodnocení výukových www stránek za stejně důležité.

$\mathbf{H}_{\mathbf{0}}$ : pořadí hodnocení jednotlivých kritérií je u mladších a starších učitelů stejné (tzv. nulová hypotéza)

$\mathbf{H}_{\mathrm{A}}$ : pořadí hodnocení jednotlivých kritérií je u mladších a starších učitelů různé (tzv. alternativní hypotéza)

Zvolená hladina významnosti $\alpha=0,05$

Jelikož $\mathrm{p}>0,05$, jak prokázal Studentův t-test, nemůžeme odmítnout nulovou hypotézu, a můžeme tedy říci, že pořadí důležitosti předložených kritérií evaluace výukových webových stránek je u skupiny mladších i starších učitelů statisticky velmi podobné.

- Spearmanův koeficient pořadové korelace: $\mathrm{r}_{\mathrm{s}}=0,86$

Spearmanův koeficient pořad. korelace

věk do 40 let věk nad 40 let

\begin{tabular}{|c|c|c|}
\hline věk do 40 let & 1 & 0,860561 \\
\hline věk nad 40 let & 0,860561 & 1 \\
\hline
\end{tabular}


Výsledek: pořadí Q-typů je u mladších i starších respondentů velmi podobné a závislost mezi hodnocenými jevy je vysoká.

Obdobné testy byly dále provedeny ve skupině respondentů výzkumu podle pohlaví, délky praxe, odborného zaměření, typu školy, sídla školy, používání výpočetní techniky, internetu a výukových webových stránek při výuce.

Použitá výzkumná metoda, pomocí které jsme ověřili námi realizovaný výzkum, je reliabilní. Reliabilitu jsme určili prostřednictvím statistických postupů s využitím programu Statistika. Vypočítaná reliabilita měření (Cronbachovo alfa: 0,955409) je velmi vysoká, získaná data lze považovat za poměrně spolehlivá a měření přesné.

U všech deseti provedených testů (podle věku, pohlaví, délky praxe, odborného zaměřní, typu školy, sídla školy, používání výpočetní techniky, internetu a výukových webových stránek) byly zjištěny statisticky shodné výsledky. Předložená kritéria hodnotily jednotlivé skupiny respondentů velmi podobně bez ohledu na jejich věk, pohlaví, délku praxe apod. a navržená kritéria lze považovat za platná pro tvorbu a hodnocení výukových webových stránek.

\section{Nejvýše byly respondenty hodnoceny následující Q-typy:}

- K 26 (celkový průměr hodnocení: 7,39) Kritérium obsahově i gramaticky správného výkladového textu se ve všech měřeních objevilo mezi prvními pěti kritérii a v 17 př́padech z 20 statistických tabulek ho respondenti stavěli na první místo.

- K29 (celkový průměr hodnocení: 6,86) Kritérium výskytu multimediálních prvků na výukové webové stránce (videozáznamy praktických činností, pokusů, měření).

- K28 (celkový průměr hodnocení: 6,57) Kritérium existence dynamických prvků webových stránek (animací - simulací, modelování jevů, postupů řešení apod.).

- K8 (celkový průměr hodnocení: 6,52) Kritérium přehlednosti hlavní navigační nabídky (menu výukové webové stránky), tedy snadná orientace ve struktuře webové stránky.

- K51 a K53 (shodný průměr hodnocení: 6,25) Kritéria využitelnosti výukové webové stránky při frontální výuce $\mathrm{v}$ počítačové učebně a současně její možné použití pro individuální výuku.

\section{Nejníže byly respondenty hodnoceny} následující Q-typy:

- K13 (celkový průměr hodnocení: 1,81) Kritérium existence informace o autorovi obsahu výukové webové stránky.

- K15 (celkový průměr hodnocení: 2,18) Kritérium existence informace o odbornosti autora výukové webové stránky.

- K16 (celkový průměr hodnocení: 2,20) Kritérium existence informace o autorských právech (tzv. copyright).

- K14 (celkový průměr hodnocení: 2,82) Kritérium existence informace o kontaktech na autora výukové webové stránky.

- K37 (celkový průměr hodnocení: 3,45) Kritérium možnosti registrace na výukové webové stránce a následné zveřejnění kontaktních údajů ostatním uživatelům webové stránky.

V jednotlivých statistických tabulkách t-testů se sice velmi zř́́dka, ale přesto objevila statisticky významně rozdílná hodnocení některých kritérií $(p<0,05)$. V t-testu závislosti na věku respondentů to byla např. kritéria $\mathrm{K} 7$ (význam hlavní navigační nabídky na každé straně) a K16 (význam informace o autorských právech). Rozdíly v hodnocení jsou však v drtivé většině př́ípadů pouze mezi $0,8-1,5$ bodu průměrného hodnocení $\mathrm{v}$ obou skupinách učitelů - respondentů výzkumu a nebudeme je tedy pokládat za výrazně statisticky významné. Zaměříme se pouze na rozdíly blížící se 2 bodům průměrného hodnocení.

V t-testu závislosti na pohlaví přikládají muži výrazněji větší význam nezávislosti fungování webové stránky na platformě prohlížeče (kritérium K4), to je možné v této skupině vysuětlit větším přehledem $v$ nabídce internetových browserů (Explorer, Firefox, Opera, Safari, Google Chrome apod.).

V t-testu závislosti na typu školy přikládají učitelé na středních školách větší význam čitelnosti textu, tedy použití vhodného barevného kontrastu s pozadím stránky (kritérium K3). Tento fakt se domníváme seriózní vysvětlení bez př́ípadné diskriminace jedné skupiny učitelů nemá. Stejně rozporuplně hodnocené se kritérium čitelnosti textu objevuje i v t-testu závislosti na velikosti obce se sídlem školy, kde mu větší význam přikládají učitelé škol, které sídlí ve větších městech a $\mathrm{v}$ t-testu závislosti na používání počítačů při výuce, kdy toto pravidlo preferují učitelé, kteří výpočetní techniku při výuce nepoužívají. 
Nepřekvapuje nejvýrazněji odlišné hodnocení kritéria K4 o nezávislosti správného zobrazení webové stránky na platformě prohlížeče, kdy učitelé informatiky toto pravidlo výrazně preferují před učiteli ostatních předmětů. U tohoto pravidla bylo dosaženo $\mathrm{v}$ obou skupinách učitelů největšího rozdílu průměrného hodnocení - 2,4 bodu.

\section{Závěr}

Jedním ze záměrů při zpracování výzkumu a tím i celé disertační práce bylo seřadit hodnocení předložených kritérií $\mathrm{v}$ jednotlivých skupinách respondentů podle aritmetického průměru a tak stanovit pořadí jejich důležitosti. Dále, v případě významnějších rozdílů v hodnocení jednotlivých kritérií např. mezi muži a ženami či mezi učiteli informatiky a učiteli ostatních předmětů, se pokusit zjistit, jaké důvody $\mathrm{k}$ danému hodnocení vedly.

Z jednotlivých statistických tabulek t-testů však vyplývá, že vhodnocení jak kritérií nejvýznamnějších, tak především kritérií nejméně důležitých panuje $\mathrm{v}$ jednotlivých skupinách učitelů shoda. Učitelé všech skupin preferují na prvním místě obsahově a gramaticky správné webové stránky, dále existenci grafiky, animací a multimediálních prvků. Velký význam přikládají respondenti přehledné navigační nabídce (menu stránek), zařazení testů, průběžných cvičení a úloh a možnost využití výukové webové stránky jak ve frontální výuce, tak při individuální výuce či samostatné práci žáků. Jako velmi specifické se ukazuje pravidlo o možném použití didaktických her, které preferují při svém hodnocení logicky především ženy, dále pak starší učitelé, učitelé s humanitním zaměřením, učitelé na základních školách a v malých obcích.

Statisticky odlišnou se pak jeví skupina učitelů informatiky, která preferuje především technická pravidla - např. nezávislost na použitém prohlížeči webových stránek, existenci fulltextové vyhledávání, virtuální reality, která se v jiných skupinách na předních pozicích v hodnocení neobjevují.

Zcela totožné je ve všech skupinách učitelů hodnocení nejméně důležitých kritérií evaluace webových stránek - jméno autora, název organizace, která stránky prezentuje, údaje o autorských právech a překvapivě i kontaktní údaje na autora výukových webových stránek.
Z provedené empirické sondy plyne, že vytvořený a výzkumem ověřený evaluační nástroj je možné využívat $v$ běžné realitě školního prostředí. Mnozí učitelé si také během vyplňování evaluačního protokolu uvědomili, jak vlastně postupovat při výběru vhodné webové stránky jako učební pomůcky. Lze proto konstatovat, že předložený evaluační nástroj by mohl některým učitelům $\mathrm{v}$ praxi posloužit mimo jiné jako metodologický průvodce. Právě díky důrazu na pedagogické a didaktické elementy by je mohl předložený evaluační nástroj motivovat $\mathrm{k}$ tomu, aby ve svých školách více prosazovali inovační styly vyučování využívající moderní didaktické elektronické prostředky.

\section{Literatura}

[1] ČERNOCHOVÁ, M. a SIŇOR, S. Využití ICT ve školni praxi. Vzdělání pro život v informační společnosti. Praha: UK, 2005. ISBN 80-7290-202-4.

[2] CHRÁSKA, M. Úvod do výzkumu v pedagogice. Olomouc: Univerzita Palackého, Pedagogická fakulta, 2003. ISBN 80-244-0765-5. [3] CHRÁSKA, M. Metody pedagogického výzkumu. Praha: Grada, 2007. 272 s. ISBN 97880-247-1369-4.

[4] GAVORA, P. Úvod do pedagogického výzkuтu. Brno: Paido, 2000. ISBN 80-85931-796.

[5] KLEMENT, M. Problematika tvorby výukového software a jeho evaluace. Disertační práce. Olomouc: Univerzita Palackého, Pedagogická fakulta, 2003.

[6] NACHMIAS, R., TUVI, I. Taxonomy of Scientifically Oriented Educational Websites (online). 1999 [cit. 2009-07-10]. URL: <http://muse.tau.ac.il/publications/jset.pdf>.

[7] PRŮCHA, J. Pedagogická evaluace. Brno: Masarykova Univerzita, 1996. 166 s. ISBN 80210-133-8.

\section{PaedDr. Petr Pexa \\ Katedra informatiky \\ Pedagogická fakulta JU \\ Jeronýmova 10 \\ 371 15, České Budějovice, ČR \\ Tel: +420 387773075 \\ E-mail: pepe@pf.jcu.cz \\ Www pracoviště: http://wvc.pf.jcu.cz/ki}

